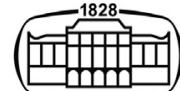

AKADÉMIAI KIADÓ

Acta Chromatographica

34 (2022) 2, 197-202

DOl:

$10.1556 / 1326.2021 .00909$

(c) 2021 The Author(s)

\section{ORIGINAL RESEARCH} PAPER

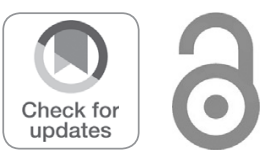

\title{
Phytochemical profiling of spiny coriander (Eryngium foetidum L.) - A potential perennial spicing-culinary herb of eastern India
}

\author{
GOBINDA CHANDRA ACHARYA ${ }^{1 *}$ (D), NARESH PONNAM ${ }^{1}$, \\ MEENU KUMARI ${ }^{1}$, TAPAS KUMAR ROY ${ }^{2}$, \\ KODTHALU SEETHARAMAIAH SHIVASHANKARA ${ }^{2}$ and \\ MANAS RANJAN SAHOO ${ }^{1 * *}$ (1)
}

\footnotetext{
${ }^{1}$ Central Horticultural Experiment Station, ICAR-Indian Institute of Horticultural Research Regional Station, Bhubaneswar, 751019, India

${ }^{2}$ Division of Plant Physiology and Biochemistry, ICAR-Indian Institute of Horticultural Research, Bengaluru, 560089, India
}

Received: March 31, 2021 - Accepted: May 8, 2021

Published online: June 8, 2021

\begin{abstract}
Spiny coriander (Eryngium foetidum L.) is a perennial medicinal herb grown in the tropical regions worldwide. In India, it is used as a potential spice for garnishing and flavoring the dishes and treating several ailments. Eryngium spp. found in coastal Odisha, India has a strong aroma similar to the seasonal Coriandrum. The volatile flavor constituents of the unique plants were analyzed through headspace solid-phase microextraction (HS-SPME) using capillary gas chromatography (GC) and gas chromatography-tandem mass spectrometry (GC-MS/MS). The volatile compounds exhibited high chemodiversity, with 10-undecenal as the major component in leaves (44.98\%) and branches (57.43\%). Fourier-transform infrared (FTIR) spectroscopy identified eight major peaks grouped into six main regions. Chemo profiles of these two corianders were overlapped and showed similar area differences in the spectral peak. The lesser-known perennial Eryngium with high chemodiversity would be a better alternative to the seasonal coriander for aromatic, pharmaceutical, and industrial uses.
\end{abstract}

\section{KEYWORDS}

FIR, GC-MS analysis, volatiles, spiny coriander, aromatic and pharmaceutical industries

\section{INTRODUCTION}

Eryngium foetidum L. belongs to the family Apiaceae is a neglected perennial herb commonly known as spiny coriander. It is extensively grown in the tropics of the world for its medicinal values and unique pungency. E. foetidum is indigenous to tropical America and Caribbean islands and was later introduced to Southeast Asian countries by the Chinese in the late 1800s. This perennial herb is grown abundantly in the poor and marginal soils of India's eastern and north-eastern parts [1]. Leaves and branches of the plant are rationally used to garnish and flavoring foods as a substitute for coriander due to similar aroma and fragrance [2]. E. foetidum also has several pharmaceutical applications such as anticlastogenic [3], antiinflammatory [4], anthelmintic and anticarcinogenic properties [1]. Leaves of this underutilized herb contain the essential oil eryngial (0.29\%, trans-2-dodecenal) have many industrial applications [5]. The Eryngium extracts, rich in eryngial have been used effectively in treating parasites [6, 7], arthritis, and skin diseases [1]. It has also been used as a major ingredient for developing skin-whitening agents [8].

E. foetidum has a broad scope from the industrial perspective because of its wide adaptability, perennial nature, and sturdy stature. With increasing health concerns, the 
demands of Eryngium leaves are increasing for medicinal and industrial uses. Due to bioactive compounds, several Eryngium spp. have been used to treat human physiological disorders [9, 10, 11]. Although reports on pharmaceutical applications of E. foetidum are available, phytochemical investigation of leaves and the branches of E. foetidum, in particular, are scanty $[12,13,14]$. Hence, the present study focused on phytochemical profiling of the leaves and branches of E. foetidum, collected from east-coast India, through GC and GC-MS/MS to explore its industrial potential.

\section{EXPERIMENTAL}

\section{Plant materials}

E. foetidum L. plants (Biological reference material numberIC 0629514) collected from Delang, Odisha, India, and Coriandrum sativum L. collected from the local market were maintained in the greenhouse at Central Horticultural Experiment Station (CHES), Bhubaneswar, India. Fresh Eryngium leaves and branches were assessed for various phytochemical compositions and compared with coriander leaf samples (C. sativum L.) using FTIR spectroscopy.

\section{FTIR analysis}

The absorption spectra were measured through FTIR spectroscopy instrument Spectrum Two (Perkin Elmer Spectrum Version 10.4.3, Waltham, Massachusetts, USA) with a detector LiTa03, and experimental results were visualized using PC-based software. Intact Eryngium and Coriandrum leaf and branch samples were used for analysis, and a thin film was used for applying optimum pressure. Absorbance was recorded in the wave range from 450 to $4000 \mathrm{~cm}^{-1}$, and functional groups in the samples were identified by comparing the spectral data with reference peaks.

\section{SPME Extraction of volatiles}

The extraction and analysis of headspace volatile compounds from leaves were studied using SPME fibers for direct sampling to avoid interference from nonvolatile matrices [15, 16, 17]. An SPME holder and three commercially available SPME fibers containing different adsorbents were obtained from Supelco Inc. (Bellefonte, PA, USA). Highly crossed linked $(50 / 30 \mu \mathrm{m})$ DVB/CAR/PDMS was optimized as the most suitable fiber and was activated at $250^{\circ} \mathrm{C}$ for $3 \mathrm{~h}$ in the injector port, followed by the extraction in the headspace.

Headspace volatile compounds from Eryngium leaves and branches were extracted following standard procedure $[15,17]$. Six leaves were ground and transferred into two separate $100-\mathrm{mL}$ conical flasks having screwcaps with a silicon rubber septum. After closing the cap, the leaves were allowed to reach room temperature $\left(25 \pm 1^{\circ} \mathrm{C}\right)$ to get equilibrated with headspace. The volatile compounds were absorbed by inserting the pre-conditioned SPME fiber into the headspace of the vial for $3 \mathrm{~h}$.

\section{Capillary gas chromatography and mass spectrometry (GC/MS)}

Gas Chromatography (GC): For GC, a Varian CP-3800 gas chromatograph with a Varian factor FOURVF-5MS silica capillary column (30 m and $0.25-\mu \mathrm{m}$ film thickness) and an FID detector was used. The SPME fiber was introduced in the injector port for $10 \mathrm{~min}$ for desorption. All injections were made in the split mode (1:5), and helium at $1 \mathrm{~mL} \mathrm{~min}^{-1}$ was used as the carrier gas. Injector and detector temperatures were set at $260^{\circ} \mathrm{C}$ and $270^{\circ} \mathrm{C}$, respectively. For the column, temperature programs were maintained as follows: $50^{\circ} \mathrm{C}$ for 5 min, increased to $170^{\circ} \mathrm{C}$ at $4^{\circ} \mathrm{C} \mathrm{min}{ }^{-1}$, then hold for $2 \mathrm{~min}$, then increased to $250^{\circ} \mathrm{C}$ at $5^{\circ} \mathrm{C} \mathrm{min}{ }^{-1}$, maintained a constant temperature for $7 \mathrm{~min}$, and total run time was $60 \mathrm{~min}$.

Gas chromatography-mass spectrometry: For resolving the components, a Varian-4000 ion-trap mass spectra detector coupled with a Varian-3800 gas chromatograph and fusedsilica capillary column VF-5MS (factor Four, Varian, USA, $30 \mathrm{~m} \times 0.25 \mathrm{~mm}$ id $0.25-\mathrm{mm}$ film thickness) was used. Helium gas with a flow rate of $1 \mathrm{~mL} \mathrm{~min}^{-1}$ was used as a carrier. Temperatures of $200^{\circ} \mathrm{C}, 240^{\circ} \mathrm{C}$, and $210^{\circ} \mathrm{C}$ were maintained for the ion trap, transfer line, and ion source, respectively. The mass spectrometer was operated in the external electron ionization mode of $70 \mathrm{eV}$, with a total mass scan range of 50-450 amu. Temperature programs for the column were the same as described for GC-FID.

The individual compounds resolved were quantified as the relative percent area and identified by comparing the retention index [18]. The spectral identification was made using the spectral libraries, Wiley-2005 and NIST-2007.

\section{RESULTS AND DISCUSSION}

\section{FIIR spectroscopy}

FTIR is known for its broad spectrum of uses ranging from chemical mapping/metabolite profiling to genotype identification [19]. In the present study, FTIR spectroscopy was used to identify functional groups between 450 and 4000 $\mathrm{cm}^{-1}$, and functional groups were resolved based on their peaks. Individual peaks were identified and characterized according to Coates (2006) [20]. Eight major peaks were obtained from both coriander and wild spiny coriander samples. These eight peaks are described in six main regions, namely, hydroxyl region (O-H stretching) at 3337-3341 $\mathrm{cm}^{-1}$, lipid region at $2918-2950 \mathrm{~cm}^{-1}$, one peak of $\mathrm{CH}_{2}$ asymmetric $\left(2918 \mathrm{~cm}^{-1}\right)$ and $\mathrm{CH}_{2}$ symmetric $\left(2950 \mathrm{~cm}^{-1}\right)$, ester and olefinic region $(\mathrm{C}=\mathrm{O}$ carbonyl stretch, $\mathrm{C}-\mathrm{H}$ aromatic stretch, and vinyl $\mathrm{C}-\mathrm{H})$ at $1605-1420 \mathrm{~cm}^{-1}$, aromatic amino groups (aromatic primary C-N stretch) at $1244 \mathrm{~cm}^{-1}$, primary and secondary alcohol stretch at $1000-1100 \mathrm{~cm}^{-1}$, and fingerprint region with several overlapping peaks at $1000-500 \mathrm{~cm}^{-1}$. The broad and strong peak centered at 3339 $\mathrm{cm}^{-1}$ represents alcohol and hydroxyl group frequencies, which results from the extensive intermolecular and intramolecular hydrogen bonding of water and biomolecules 
having $-\mathrm{NH}$ and $-\mathrm{OH}$ groups in a chemical structure [21, 22]. The spectra results indicated the presence of a narrow and sharp peak for $-\mathrm{CH}_{2}$ asymmetric and symmetric stretching vibrations at 2918 and $2950 \mathrm{~cm}^{-1}$, respectively. The integrated absorption (indicated in parentheses) by spiny coriander and coriander showed substantial longchain fatty acids to spectral features in the lipid region. FTIR spectra for the carbonyl group are characteristic in the wave range $1605-1630 \mathrm{~cm}^{-1}$ located at $1618 \mathrm{~cm}^{-1}$ assigned for $\mathrm{C}=\mathrm{O}$ ester and $\mathrm{C}-\mathrm{H}$ aromatic, which might be due to the decenal group $\left(\mathrm{C}_{12} \mathrm{H}_{22} \mathrm{O}\right)$ and trimethylbenzaldehyde. The broad peak of the alkene group at $1419 \mathrm{~cm}^{-1}$ indicates unsaturated hydrocarbons that contribute to approximately $22 \%$ of total isolated compounds (Table 1). The small peak at $1244 \mathrm{~cm}^{-1}$ is considered for aromatic C-N stretch as $1250-1360 \mathrm{~cm}^{-1}$ is characteristically identified for primary, secondary, and tertiary aromatic amino groups [20]. These characteristic absorbance spectra present in the IR region of Coriandrum and Eryngium are considered spectral characteristics of flavoring compounds. The wave range 1014-1105 $\mathrm{cm}^{-1}$ corresponded to the alcohol stretch spectral features with primary and secondary bonds, respectively. The overlapping peaks in the wave range $450-1000 \mathrm{~cm}^{-1}$ are considered the fingerprint region. The Eryngium and Coriandrum profiles were overlapped, and similar patterns were observed for both the corianders with area differences in the spectral peak. Based on the above interpretation, referral spectra (Fig. 1) depicting all identified regions for coriander or coriander group plants like Culantro and Vietnamese coriander. In our study, eight major peaks were obtained from both coriander and wild spiny coriander samples (Fig. 1). The FTIR spectroscopy preliminarily showed the comparable potential of perennial spiny coriander with the perishable seasonal coriander. The result suggests further partitioning of volatile and non-volatile compounds in this lesser-known spiny coriander for exploration as a commercial food crop for industrial importance.

Table 1. FTIR peak and integrated peak area, comparison of Eryngium foetidum and Coriandrum sativum

\begin{tabular}{|c|c|c|c|c|c|c|c|}
\hline \multirow{2}{*}{$\begin{array}{l}\text { Peak } \\
\text { no. }\end{array}$} & \multirow{2}{*}{$\begin{array}{l}\text { Wavelength } \\
\text { range }\end{array}$} & \multirow{2}{*}{$\begin{array}{c}\text { Peak } \\
\text { centre }\end{array}$} & \multicolumn{2}{|c|}{ E. foetidum } & \multirow{2}{*}{$\begin{array}{c}\text { C. } \\
\text { sativum }\end{array}$} & \multirow[b]{2}{*}{ Functional group } & \multirow[b]{2}{*}{ Reference } \\
\hline & & & leaf & branch & & & \\
\hline 1. & $3337-3341$ & 3339 & $\begin{array}{c}3339 \\
(65.04)\end{array}$ & $\begin{array}{c}3341 \\
(66.20)\end{array}$ & $\begin{array}{c}3338 \\
(74.94)\end{array}$ & $\begin{array}{l}\text { Intermolecular bonded alcohol } \\
\text { O-H stretching }\end{array}$ & Silverstein et al., 2005 [19] \\
\hline 2. & 2918 & 2918 & $\begin{array}{l}2918 \\
(2.59)\end{array}$ & $\begin{array}{c}2918 \\
(2.51)\end{array}$ & $\begin{array}{l}2918 \\
(1.7)\end{array}$ & $\mathrm{CH}_{2}$ asymmetric & Silverstein et al., 2005 [19] \\
\hline 3. & 2850 & 2850 & $\begin{array}{l}2850 \\
(3.66)\end{array}$ & $\begin{array}{c}2851 \\
(2.77)\end{array}$ & $\begin{array}{l}2850 \\
(2.33)\end{array}$ & $\mathrm{CH}_{2}$ symmetric & Silverstein et al., 2005 [19] \\
\hline 4. & $1605-1630$ & 1630 & $\begin{array}{l}1618 \\
(9.88)\end{array}$ & $\begin{array}{c}1632 \\
(10.68)\end{array}$ & $\begin{array}{c}1632 \\
(8.22)\end{array}$ & $\mathrm{C}=\mathrm{O}$ ester, $\mathrm{C}-\mathrm{H}$ aromatic & Silverstein et al., 2005 [19] \\
\hline 5. & $1415-1420$ & 1419 & $\begin{array}{c}1419 \\
(1.53)\end{array}$ & $\begin{array}{c}1418 \\
(1.82)\end{array}$ & NA & $\begin{array}{l}\text { Vinyl C-H in plane bend } \\
\text { (olefenic/alkene group) }\end{array}$ & Silverstein et al., 2005 [19] \\
\hline 6. & 1244 & 1244 & NA & NA & $\begin{array}{l}1244 \\
(0.79)\end{array}$ & $\begin{array}{c}\text { Aromatic primary amine, } \mathrm{C}-\mathrm{N} \\
\text { stretch }\end{array}$ & Silverstein et al., 2005 [19] \\
\hline 7. & $1100-1105$ & 1102 & $\begin{array}{c}1100 \\
(0.88)\end{array}$ & $\begin{array}{c}1098 \\
(0.08)\end{array}$ & $\begin{array}{c}1104 \\
(0.62)\end{array}$ & Secondary alcohol, C-O stretch & $\begin{array}{l}\text { Marechal and Chanzy, } \\
2000[31]\end{array}$ \\
\hline 8. & $1014-1019$ & 1017 & $\begin{array}{c}1015 \\
(1.81)\end{array}$ & $\begin{array}{l}1030 \\
(0.08)\end{array}$ & $\begin{array}{r}1019 \\
(0.44)\end{array}$ & Primary alcohol, C-O stretch & $\begin{array}{l}\text { Marechal and Chanzy, } \\
2000[31]\end{array}$ \\
\hline 9. & $450-1000$ & \multicolumn{4}{|c|}{ Overlapping peaks } & Fingerprint region & Silverstein et al., 2005 [19] \\
\hline
\end{tabular}

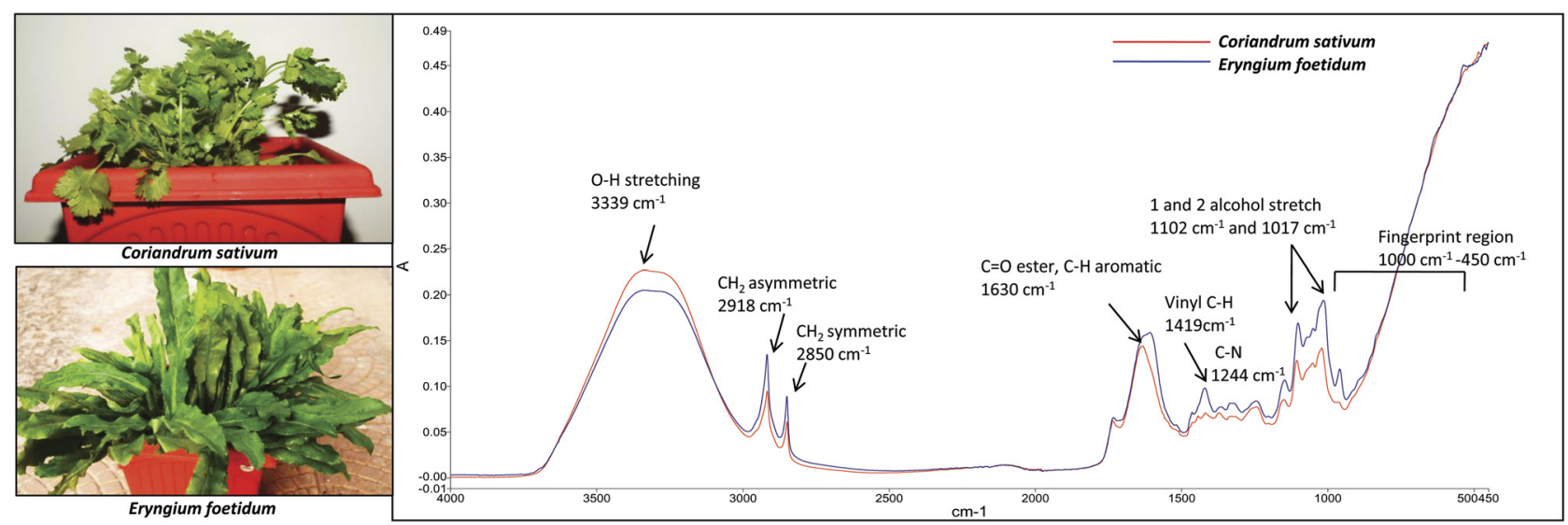

Fig. 1. Spectral characteristics of Eryngium foetidum L. and Coriandrum sativum L. through Fourier-transform infrared (FTIR) spectroscopy 


\section{GC-MS analysis}

GC and GC-MS identified 77 compounds in the leaf, and 79 compounds in the branch (Table 2) of E. foetidum L. (IC0629514) collected from Odisha, India. In leaf volatile compounds, the major portion was contributed by aldehydes and ketones $(64.63 \%)$, followed by $22.07 \%$ hydrocarbons, $7.61 \%$ alcohols, and $6 \%$ acids and oxygenated compounds. Among the aldehydes and ketones with high economic importance in aromatic industries, 10 -undecenal is the dominant constituent (44.98\%). (Z)-7-tetradecenal (4.35\%) and (Z)-9-tetradecenal (5.42\%) were other compounds of the decenal group. The isomers of trimethylbenzaldehyde [2,4,6-trimethylbenzaldehyde (7.81\%) and 2,4,5-trimethylbenzaldehyde $(0.41 \%)$ ] are isolated moderately. These isomers were reportedly contributing to fragrance in Eryngium accessions of Cuba (2,4,5-trimethylbenzaldehyde; 20.53\%) [23], Portugal (2,3,6-trimethylbenzaldehyde; 23.7\%) [24], and Port Blair (trimethylbenzaldehyde; 16.5\%) [25].

The cis-2-methyl-2-butenoic acid (0.03\%) and caryophyllene oxide $(0.25 \%)$ are major constituents among acids and oxygenated compounds, respectively. Beta-caryophyllene $(7.09 \%)$, trans-beta-farnesene $(3.56 \%)$, valencene (2.39\%), germacrene D (1.51\%), beta-gurjunene $(1.45 \%)$, beta-bisabolene (1.39\%), (Z,E)-alpha-farnesene (1.22\%), and isoledene $(1.06 \%)$ were important compounds among hydrocarbons. (Z)6-(Z)9-pentadecadiene-1-ol (2.31\%), 1-decanol (1.39\%), (Z)-7-tetradecenol (1.35\%), and carotol (1.02\%) were major compounds of alcohols.

The branches of E. foetidum L. contained the same compounds as leaves. Four primary aliphatic aldehydes [10undecenal (57.43\%), (Z)-9-tetradecenal (6.67\%), (Z)-7-tetradecenal (5.34\%), and 2,4,6-trimethylbenzaldehyde $(4.14 \%)]$ contributed the highest $(73.58 \%)$, which is $10 \%$ more than its leaf aldehydes. Only three hydrocarbons namely, beta-caryophyllene (4.9\%), beta-gurjunene (3.61\%), and trans-beta-farnesene $(1.55 \%)$, and three alcoholic compounds, 1-decanol (1.24\%), (Z)-7-tetradecenol (1.88\%), and (Z)6-(Z)9-pentadecadiene-1-ol (1.26\%), contributed above $1 \%$. These hydrocarbons and alcoholic compounds also contributed more than $1 \%$ of their leaf essential oils. Almost the same proportion of acids and oxygenated compounds was present in the essential oil from the branches and leaves. The leaves with the branch portion of this sturdy herb may be used for isolation of the flavoring compounds.

The chemical constituents reportedly varied among the Eryngium spp. collected from different geographical locations. However, (E)-2-dodecanal, a major aliphatic aldehyde compound found common in Eryngium leaves of various geographical origins such as the Vietnam origin (45.5\%) [26], Peang Hill (Malaysia) origin (59.7\%) [27], Bangladesh origin (37.5\%) [12], Northeastern hill region of India (38.9\%) [1], Southern Vietnam origin $(57.8 \%-67.1 \%)$ [28], Peruvian origin $(61.6 \%-62.2 \%)$ [29], and Nadugani Indian accessions (2.8\%) [25]. In the Eastern Ghats genotypes of India, (E)-2-dodecanal was found in a minor quantity in leaf $(0.021 \%)$ and branch $(0.032 \%)$ [25]. Wide variation in the (E)-2-dodecanal content probably due to the adverse
Table 2. Percentage composition of different compounds in leaves and branches of Eryngium foetidum L. analyzed through GC and GC-MS

\begin{tabular}{|c|c|c|c|}
\hline \multirow[b]{2}{*}{ Compounds Identified } & \multirow{2}{*}{$\begin{array}{l}\text { K.I } \\
\text { Cal. }\end{array}$} & \multicolumn{2}{|c|}{$\%$ composition } \\
\hline & & Leaf & Branch \\
\hline \multicolumn{4}{|l|}{ Hydrocarbons } \\
\hline Toluene & 762 & 0.008 & 0.01 \\
\hline$\alpha$-Thujene & 923 & 0.008 & 0.005 \\
\hline$\alpha$-Pinene & 932 & 0.225 & 0.099 \\
\hline Sabinene & 971 & 0.034 & 0.018 \\
\hline$\beta$-Pinene & 978 & 0.334 & 0.259 \\
\hline trans-4-Decene & 995 & 0.010 & 0.116 \\
\hline Decane & 1000 & 0.179 & 0.086 \\
\hline$\delta$ - 3-carene & 1009 & 0.003 & 0.004 \\
\hline 1,2,3-Trimethylbenzene & 1017 & 0.037 & 0.123 \\
\hline$\alpha$-Terpinene & 1019 & 0.003 & 0.002 \\
\hline Limonene & 1033 & 0.161 & 0.126 \\
\hline cis-Ocimene & 1026 & 0.016 & 0.008 \\
\hline$\beta$-Ocimene & 1041 & 0.014 & 0.001 \\
\hline Benzene, 1-methyl-4-(2-propenyl)- & 1048 & 0.008 & 0.008 \\
\hline$\gamma$-Terpinene & 1062 & 0.307 & 0.192 \\
\hline Terpinolene & 1085 & 0.003 & 0.002 \\
\hline 3-Butyl-4-vinyl-1-cyclopentene & 1092 & 0.007 & 0.003 \\
\hline 4-Decene, 4-methyl-, (E)- & 1100 & 0.003 & 0.009 \\
\hline 2,6-Dimethyl-1,3,5,7-octatetraene, E,E- & 1115 & 0.004 & 0.003 \\
\hline 1-Dodecyne & 1212 & 0.019 & 0.024 \\
\hline P-Cymene & & 0.100 & 0.117 \\
\hline Azulene & 1305 & 0.001 & 0.007 \\
\hline$(+)$-Cyclosativene & 1317 & 0.180 & 0.055 \\
\hline (-)-Isosativene & 1339 & 0.089 & 0.043 \\
\hline (-)-Isoledene & 1381 & 1.067 & 0.398 \\
\hline$\beta$-Gurjunene & 1405 & 1.454 & 3.615 \\
\hline Thujopsene & 1421 & 0.126 & 0.128 \\
\hline$\beta$-Caryophyllene & 1427 & 7.091 & 4.903 \\
\hline$\alpha$-Bergamotene & 1432 & 0.350 & 0.152 \\
\hline Germacrene D & 1464 & 1.517 & 0.735 \\
\hline$(+)$-Valencene & 1474 & 2.396 & 0.152 \\
\hline$(\mathrm{Z}, \mathrm{E})-\alpha$-Farnesene & 1478 & 1.229 & 0.464 \\
\hline$\gamma$-Muurolene & 1486 & 0.506 & 0.198 \\
\hline trans- $\beta$-Farnesene & 1506 & 3.563 & 1.552 \\
\hline$\beta$-Bisabolene & 1512 & 1.390 & 0.000 \\
\hline$(-)$ - $\beta$-Cadinene & 1518 & 0.329 & 0.000 \\
\hline \multicolumn{4}{|l|}{ Alcohols } \\
\hline Cis-3-Hexen-1-ol & 852 & 0.135 & 0.098 \\
\hline 1-Hexanol & 864 & 0.017 & 0.010 \\
\hline 5-Octen-1-ol, (Z)- & 1067 & 0.038 & 0.047 \\
\hline 3-Nonen-1-ol, (E)- & 1167 & 0.022 & 0.030 \\
\hline Methyl Chavicol & 1192 & 0.112 & 0.118 \\
\hline E-2-Decenol & 1261 & 0.021 & 0.032 \\
\hline 1-Decanol & 1268 & 1.396 & 1.249 \\
\hline 2,4-Undecadien-1-ol & 1379 & 0.203 & 0.216 \\
\hline 2,4-Undecadienol & 1385 & 0.000 & 0.051 \\
\hline 8,10-Dodecadien-1-ol, (E,E)- & 1473 & 0.033 & 0.000 \\
\hline 6-Dodecenol & 1485 & 0.340 & 0.318 \\
\hline$(2 \mathrm{E}, 4 \mathrm{E})-2,4$-Decadien-1-ol & 1491 & 0.000 & 0.029 \\
\hline Nerolidol & 1564 & 0.228 & 0.090 \\
\hline 5,7undecadienol & 1583 & 0.286 & 0.379 \\
\hline$(+)$-Carotol & 1591 & 1.026 & 0.268 \\
\hline (Z)-7-Tetradecenol & 1663 & 1.350 & 1.880 \\
\hline (Z)-9-Tetradecen-1-ol & 1671 & 0.152 & 0.548 \\
\hline
\end{tabular}


Table 2. Continued

\begin{tabular}{|c|c|c|c|}
\hline \multirow[b]{2}{*}{ Compounds Identified } & \multirow{2}{*}{$\begin{array}{l}\text { K.I } \\
\text { Cal. }\end{array}$} & \multicolumn{2}{|c|}{$\%$ composition } \\
\hline & & Leaf & Branch \\
\hline (Z)6-(Z)9-Pentadecadiene-1-ol & 1782 & 2.315 & 1.258 \\
\hline \multicolumn{4}{|l|}{ Aldehydes and Keto } \\
\hline 1-Hexanal & 788 & 0.006 & 0.005 \\
\hline (E)-2-Hexenal & 860 & 0.191 & 0.103 \\
\hline (Z)-6-Nonenal & 1102 & 0.121 & 0.650 \\
\hline 2,4-Dimethylbenzaldehyde & 1180 & 0.042 & 0.094 \\
\hline (4E)-4-Undecenal & 1191 & 0.470 & 0.734 \\
\hline Safranal & 1198 & 0.104 & 0.092 \\
\hline$\beta$-Cyclocitral & 1210 & 0.012 & 0.003 \\
\hline (Z)-2-Decenal & 1253 & 0.354 & 0.128 \\
\hline (2E,4E)-2,4-Decadienal & 1288 & 0.055 & 0.033 \\
\hline 10-Undecenal & 1293 & 44.981 & 57.438 \\
\hline 2,4,5-Trimethylbenzaldehyde & 1301 & 0.414 & 0.299 \\
\hline Benzaldehyde, 2,4,6-trimethyl- & 1316 & 0.000 & 0.014 \\
\hline 2,4,6-Trimethylbenzaldehyde & 1324 & 7.811 & 4.142 \\
\hline 7- dodecen-1 -al & 1395 & 0.017 & 0.064 \\
\hline $\begin{array}{l}\text { 5,9,9-Trimethylspiro[3.6]deca-5,7-dien- } \\
\text { 1-one }\end{array}$ & 1473 & 0.000 & 0.005 \\
\hline (E,E)-2,4-Dodecadien-1-al & 1491 & 0.000 & 0.224 \\
\hline Z-7-Tetradecenal & 1585 & 4.359 & 5.347 \\
\hline (Z)-9-Tetradecenal & 1606 & 5.421 & 6.678 \\
\hline 13-Tetradecenal & 1610 & 0.008 & 0.007 \\
\hline (Z)-9-Hexadecenal & 1792 & 0.157 & 0.235 \\
\hline (13Z)-13-Octadecenal & 2007 & 0.172 & 0.018 \\
\hline Acids & & & \\
\hline $\begin{array}{l}\text { cis-2-Methyl-2-butenoic acid } \\
\text { Oxygenated }\end{array}$ & 860 & 0.033 & 0.031 \\
\hline $\begin{array}{l}\text { Pyrazine, 2-methoxy-3-(1- } \\
\text { methylpropyl)- }\end{array}$ & 1175 & 0.004 & 0.004 \\
\hline $\begin{array}{l}\text { 2-Isopropyl-1-methoxy-4- } \\
\text { methylbenzene }\end{array}$ & 1231 & 0.019 & 0.002 \\
\hline 2-Pentyl furan & & 0.060 & 0.080 \\
\hline 2-Octylfuran & 1290 & 0.088 & 0.060 \\
\hline $\begin{array}{l}\text { 2-Chloro-5-methoxy-1,3- } \\
\text { dimethylbenzene }\end{array}$ & 1292 & 0.004 & 0.014 \\
\hline Caryophyllene oxide & 1581 & 0.254 & 0.310 \\
\hline
\end{tabular}

climatic factors and herbage. The well-known spicy herb coriander leaves are the primary source of decanal group volatile compounds such as (E)-2-decanal, (E)-2-dodecanal, (E)-2-undecanal, and (E)-2-tetradecanal of coriander leaves and herb $[19,30]$. The phytochemical study of spiny coriander shows that the 10-undecenal group $\left(\mathrm{C}_{10}\right)$ is the major component that attributes to aromatics, indicating the herb can be used as a substitute for Coriandrum in pharmaceutical industries.

\section{CONCLUSIONS}

Eryngium collected from Odisha, India, exhibited high chemodiversity with 10-undecenal as the major component in leaves (44.98\%) and branches (57.43\%) followed by 2,4,6 trimethylbenzaldehyde $(7.81 \%$ in leaves and $4.14 \%$ in the branches), (Z)-9-tetradecenal (5.42\% in leaves and $6.67 \%$ in the branches), and (Z)-7-tetradecenal (4.35\% in leaves and $5.34 \%$ in the branches). Chemo profiles of these two corianders, Eryngium and Coriandrum, were overlapped and showed similar area differences in the spectral peak. Perennial sturdy Eryngium, well suited to poor and marginal soils, can be promoted for large-scale production of aromatic compounds and flavonoids for industrial use alternate to perishable seasonal Coriandrum.

Disclosure statement: The authors declare that there is no conflict of interest.

Author contribution statement: GCA: Conceptualization, Validation, Writing -original draft, Supervision. NP: Methodology, Investigation, Formal analysis, Writing -original draft. MK: Methodology, Investigation, Formal analysis, Writing -original draft. TKR: Investigation, Formal analysis. KSS: Formal analysis. MRS: Validation, Writing -review and editing.

\section{ACKNOWLEDGEMENTS}

The authors thank the Director of the Indian Institute of Horticultural Research, Bengaluru, India, for providing facilities and Central Instrumentation Facilities (CIF), Odisha University of Agriculture and Technology, India for FTIR analysis of the samples.

\section{REFERENCES}

1. Singh, B. K.; Ramakrishna, Y.; Ngachan, S. V. Spiny coriander (Eryngium foetidum L.): a commonly used, neglected spicing-culinary herb of Mizoram, India. Genet. Resour. Crop Evol. 2014, 61, 1085-90. https://doi.org/10.1007/s10722-014-0130-5.

2. Wei, J. N.; Liu, Z. H.; Zhao, Y. P.; Zhao, L. L.; Xue, T. K.; Lan, Q. K. Phytochemical and bioactive profile of Coriandrum sativum $\mathrm{L}$. Food Chem. 2019, 286, 260-7. https://doi.org/10.1016/j.foodchem. 2019.01.171.

3. Promkum, C.; Butryee, C.; Tuntipopipat, S.; Kupradinun, P. Anticlastogenic effect of Eryngium foetidum L. Assessed by erythrocyte micronucleus assay. Asian Pac. J. Cancer Prev. 2012, 13, 3343-7. https://doi.org/10.7314/APJCP.2012.13.7.3343.

4. Mekhora, C.; Muangnoi, C.; Chingsuwanrote, P.; Dawilai, S.; Svasti, S.; Chasri, K.; Tuntipopipat, S. Eryngium foetidum suppresses inflammatory mediators produced by macrophages. Asian Pac. J. Cancer Prev. 2012, 13, 723-34. https://doi.org/10.7314/APJCP. 2012.13.2.653.

5. Flamini, G.; Tebano, M.; Cioni, P. L. Composition of the essential oils from leafy parts of the shoots, flowers and fruits of Eryngium amethystinum from Amiata Mount (Tuscany, Italy). Food Chem. 2008, 107, 671-4. https://doi.org/10.1016/j.foodchem.2007.08.064.

6. Forbes, W. M.; Reese, P. B.; Robinson, R. D. Medicaments for the Treatments of Strongyloides Stercoralis Infections, The University of the West Indies and Scientific Research Council, Jamaica, 2002, Patent \#3325. 
7. Forbes, W. M.; Steglich, C. Methods of Treating Infectious Diseases, Slippery Rock University, Slippery Rock, Philadelphia, PA, USA, 2007, US Patent \#20090047342.

8. Yagi, E.; Ota, N.; Fujiwara, R.; Umishio, K. Skin-whitening Agent. SHISEIDO Co Ltd, 2006, Japanese Patent \#JP2006265141.

9. Ben, L. H.; Pasini, F.; Politowicz, J.; Tlili, N.; Khaldi, A.; Caboni, M. F.; Nasri, N. Lipid characterization of Eryngium maritimum seeds grown in Tunisia. Ind. Crops Prod. 2017, 105, 47-52. https://doi. org/10.1016/j.indcrop.2017.05.001.

10. Vukic, M. D.; Vukovic, N. L.; Djelic, G. T.; Obradovic, A.; Kacaniova, M. M.; Markovic, S.; Popović, S.; Baskić, D. Phytochemical analysis, antioxidant, antibacterial and cytotoxic activity of different plant organs of Eryngium serbicum L. Ind. Crops Prod. 2018, 115, 88-97. https://doi.org/10.1016/j.indcrop.2018.02.031.

11. Ayuso, M.; Pinela, J.; Dias, M. I.; Barros, L.; Ivanov, M.; Calhelha, R. C.; Soković, M.; Ramil-Rego, P.; Barreal, M. E.; Gallego, P. P.; Ferreira, I. C. F. R. Phenolic composition and biological activities of the in vitro cultured endangered Eryngium viviparum. J. Gay. Ind. Crops Prod. 2020, 148, 112325. https://doi.org/10.1016/j.indcrop.2020.112325.

12. Chowdhury, J. U.; Nandi, N. C.; Yusuf, M. Chemical constituents of essential oil of the leaves of Eryngium foetidum from Bangladesh. Bangladesh J. Sci. Ind. Res. 2007, 42, 347-52.

13. Paul, J.; Seaforth, C. E.; Tikasingh, T. Eryngium foetidum L.: a review. Fitoterapia 2011, 82(3), 302-3. https://doi.org/10.1016/j.fitote. 2010.11.010.

14. Chandrika, R.; Sarawasthi, K. J. T.; Shivakameshwari, M. N. Phonological events of Eryngium foetidum L. from Karnataka, India. Int. J. Plant Reprod. Biol. 2013, 5(1), 89-91.

15. Jirovetz, L.; Smith, D.; Buchbauer, G. Aroma compound analysis of Eruca sativa (Brassicaceae) SPME headspace leaf samples using GC, GC-MS, and olfactometry. J. Agric. Food Chem. 2002, 50(16), 4643-6. https://doi.org/10.1021/jf020129n.

16. Flamini, G.; Cioni, P. L.; Morelli, I. Use of solid-phase microextraction as a sampling technique in the determination of volatiles emitted by flowers, isolated flower parts and pollen. J. Chromatogr. A. 2003, 998(1-2), 229-33. https://doi.org/10.1016/S0021-9673(03) 00641-1.

17. Johnson, C. B.; Kazantzis, A.; Skoula, M.; Mitteregger, U.; Novak, J. Seasonal, populational and ontogenic variation in the volatile oil content and composition of individuals of Origanum vulgare subsp. Hirtum, assessed by GC headspace analysis and by SPME sampling of individual oil glands. Phytochem. Anal. 2004, 15(5), 286-92. https://doi.org/10.1002/pca.780.

18. Bhuiyan, M. N. I.; Begum, J.; Sultana, M. Chemical composition of leaf and seed essential oil of Coriandrum sativum L. from Bangladesh. Bangladesh J. Pharmacol. 2009, 4(2), 150-3. https:// doi.org/10.3329/bjp.v4i2.2800.
19. Silverstein, R. M.; Webster, X. F.; Kiemle, D. J. Spectrometric Identification of Organic Compounds, 7th Edition; John Wiley \& Sons, INC., 2005.

20. Coates, J. Interpretation of infrared spectra, A practical approach. In Encyclopedia of Analytical Chemistry, 2006. https://doi.org/10. 1002/9780470027318.a5606.

21. Stuart, B. Infrared spectroscopy. In Kirk-Othmer Encyclopedia of Chemical Technology, Wiley online library, 2005.

22. Boczkowska, M.; Zebrowski, J.; Nowosielski, J.; Kordulasińska, I.; Nowosielska, D.; Podyma, W. Environmentally-related genotypic, phenotypic and metabolic diversity of oat (Avena sativa L.) landraces based on 67 Polish accessions. Genet. Resour. Crop Evol. 2017, 64, 1829-40. https://doi.org/10.1007/s10722-017-0555-8.

23. Pino, J. A.; Rosado, A.; Fuentes, V. Composition of the leaf oil of Eryngium foetidum L. from Cuba. J. Essent. Oil Res. 1997, 9, 467-8. https://doi.org/10.1080/10412905.1997.9700751.

24. Martins, A. P.; Salgueiro, L. R.; Da Cunha, A. P.; Vila, R.; Cañigueral, S.; Tomi, F.; Casanova, J. Essential oil composition of Eryngium foetidum from S. Tomé e Príncipe. J. Essent. Oil Res. 2003, 15, 93-5. https://doi.org/10.1080/10412905.2003.9712077.

25. Chandrika, R.; Thara Saraswathi, K. J.; Mallavarapu, G. R. Constituents of the essential oils of the leaf and root of Eryngium foetidum L. from two locations in India. J. Essent. Oil-Bearing Plants 2015, 18(2), 349-58. https://doi.org/10.1080/0972060X.2014. 960277.

26. Leclercq, P. A.; Duñg, N. X.; Lô, V. N.; Toanh, N. V. Composition of the essential oil of Eryngium foetidum L. From Vietnam. J. Essent. Oil Res. 1992, 4, 423-4. https://doi.org/10.1080/10412905. 1992.9698097.

27. Wong, K. C.; Feng, M. C.; Sam, T. W.; Tan, G. L. Composition of the leaf and root oils of Eryngium foetidum L. J. Essent. Oil Res. 1994, 6, 369-74. https://doi.org/10.1080/10412905.1994.9698401.

28. Thi, N. D. T.; Anh, T. H.; Thach, L. N. The essential oil composition of Eryngium foetidum L. In South Vietnam extracted by hydrodistillation under conventional heating and microwave irradiation. J. Essent. Oil-Bearing Plants 2008, 11, 154-61. https://doi. org/10.1080/0972060X.2008.10643612.

29. Banout, J.; Havlik, J.; Kulik, M.; Kloucek, P.; Lojka, B.; Valterova, I. Effect of solar drying on the composition of essential oil of sacha culantro (Eryngium foetidum 1.) grown in the peruvian amazon. J. Food Process. Eng. 2010, 33, 83-103. https://doi.org/10.1111/j.17454530.2008.00261.x.

30. Potter, T. L. Essential oil composition of cilantro. J. Agric. Food Chem. 1996. https://doi.org/10.1021/jf950814c.

31. Marechal, Y.; Chanzy, H. The hydrogen bond network in I $\beta$ cellulose as observed by infrared spectrometry. J. Mol. Struc. 2000, 523(1-3), 183-96. https://doi.org/10.1016/s0022-2860(99)00389-0. 